\title{
APPLICATION OF REMOTE SENSING METHOD FOR DETERMINATION OF ARABLE LAND DEGRADATION
}

\author{
Velta Parsova $^{1}$, Nataliia Stoiko ${ }^{2}$, Nadiia Kryshenyk ${ }^{3}$, Natig Mirzayev ${ }^{4}$ \\ ${ }^{1}$ Latvia University of Life Sciences and Technologies, Latvia; \\ ${ }^{2}$ Lviv National Agrarian University, Ukraine; \\ ${ }^{3}$ Lviv Polytechnic National University, Ukraine; \\ ${ }^{4}$ Lankaran State University, Azerbaijan \\ velta@parsova.lv,n_stoiko@ukr.net,nadya_kryshenyk@ukr.net, mirzoev.n@mail.ru
}

\begin{abstract}
The article studies an issue of application of remote sensing technology for determination of arable land degradation. Under the modern land use conditions, the processes of soil layer destruction, particularly on arable land, have been recognized as negative large-scale development factor. It is caused byimpact of excessive anthropogenic processes on agriculture land. The authors analyse determination of arable land degradation, using data of transformations of the vegetation cover, referring to the space multispectral satellite images Landsat. The process of investigationrequires anti-erosion organization of the territory. While processing multispectral satellite images, the principal task is to reproduce the information, which provides the best depiction of the processes of arable land degradation. Transformation of vegetation cover and dynamics of the processes of soil erosion have been chosen as indicators, characterizing arable land degradation. To measure these indicators, it is necessary to use multispectral satellite images of the medium spatial resolution along with supplementary geospatial data - digital model of topography, soil map and climatic characteristics of the studied territory. The authors of the article have performed estimation of the erosion processes by determination of the Normalized Difference Vegetation Index (NDVI). According to the results of the conducted research, the authors have developed thelocal level thematicland degradation map on the territory of village Velyka Ozymyna in Lviv region.This map demonstrates that in the period 2000-2019 $18 \%$ of the studied territory was subjected to degradation processes. Considering the discovered changes in land use, the authorsperformed modelling of the expected land degradation level on the studied territory by 2050.According to the data of modern remote sensing, it is possible to make forecast concerning the progress of soil destruction and arable land degradation in the future. It will secure efficient decision-making on optimization of agricultural land use and land protective activities.
\end{abstract}

Keywords: arable land, degradation, erosion, soil, satellite images.

\section{Introduction}

At all stages of humanity development, land resources have been and still are the main assets of agricultural production. Under modern conditions of land use, the area of agricultural land is limited, whereas the loss of each hectare causes losses for the society. Nevertheless, the anthropogenic burden on land resources is annually intensified due to growth of global population and improvement of technological equipment of production. It results in deterioration of land ecological conditions [1].

Arable land is the principal land for production of crop products. The Food and Agriculture Organization (FAO) defines that such land includes the land under temporary crops (double-cropped areas are counted only once), temporary meadows for mowing or pasture, land under kitchen gardens and land temporarily fallow (less than five years) [2]. This land is regularly treated (cultivated) normally in the system of crop rotation [3].For the period 1961-2015, the area of arable land in the world increased by $1.2 \%$, whereas in terms of population, it reduced from 0.4 to 0.2 ha per person [4]. Such statistics confirms increasing deficit of arable land.

According to the strategic calculations, there are approximately 2.7 billion ha of land with potential for production of agricultural crops in the world. This landis concentrated in the countries of Africa southward from Sahara, Southern and Central America [5]. However, expansion of the area of arable land causes felling of trees, marches graining, destruction of natural grass vegetation, making negative impact on ecological conditions of ecosystems and their biodiversity [6].

On the other hand, arable land, which is already cultivated, is subjected to heavy degradation. Analysts of the mentioned problem declare that average index of soil loss in the European Union is estimated as almost $2.5 \mathrm{t} / \mathrm{ha}$ annually. Among all kinds of land, arable land and sparse vegetation demonstrate the highest figures of soil loss. Soil erosion is the main reason of such loss [7]. 
Degradation of arable land is a global ecological problem of humanity, which makes negative impact on economic and social development of society. Solution of the problems of cease of processes of arable land degradation and protection of soil fertility is viewed through practical application of sustainable land management [8]. Efficiency of the approved decisions on protection of arable land greatly depends on reliability of the information about conditions and tendencies of degradation development. Using information about physical conditions of land surface can be determined the degree of land cover degradation by definite classification features [9]. However, under current conditions, the dynamic development of land use requires fast and appropriate detection of processes of land cover degradation, as well as forecasting of progress of negative phenomena. In that context, particular attention should be paid to the methods of detection and identification of the manifestations of the degradation process of arable land under specific local conditions with application of modern satellite technologies. Thus, the article studies the problems of degradation of arable land at the local level with application of the data of remote sensing of the Earth surface.

\section{Materials and methods}

Degradation of arable land in Latvia, Ukraine and Azerbaijan is manifested in different ways. However, soil erosion is a common problem. In Latvia, water erosion has damaged $24 \%$ of arable land, wind erosion $-15 \%$, in Ukraine $-40 \%$ and $18 \%$ respectively, in Azerbaijan - above $43 \%$ of the total area (70-85\% in some regions) is damaged by erosion processes.

The experiment was conducted on arable land within the boundaries of Ukraine, because among all countries, analysed by the FAO in 2016, Ukraine took the second position by the area of arable land (56.6\% of the total area) [4].

The research was conducted in several stages:

- analysis of development of arable land degradation through determination of changes in vegetation cover according to the space multispectral satellite images Landsat-5; Landsat-8;

- estimation of erosion processes on the base of determination of the Normalized Difference Vegetation Index NDVI;

- composing of a map of arable land degradation, which supplies visualization of aggravating of soil erosion processes;

- modelling of the current and forecasted level of erosion degradation of the territory.

To obtain the operative and reliable primary information about soil cover layer and cultivated agricultural crops, the experiment was conducted with involvement of remote sensing of the Earth (RSE), while studying degradation of arable land, with use of multispectral space images as the information base to determine the potential deterioration of land quality [10]. The main task of processing of multispectral images is to restore the information, which supplies the most adequate picture of degradation processes with specification of the indicators of land degradation. The indicators, characterizing degradation of arable land, include changes of vegetation cover and dynamics of processes of soil erosion.

Estimation of the degree of degradation of arable land on the territory of Ukraine was made with application of methods of mapping of land degradation on the base of two-level model of processing of multispectral satellite images and statistical overlapping of data [11]. Mapping was conducted by means of the software ArcGIS.

Determination of degradation of arable land by materials of satellite images of high resolution was performed in the following order, particularly, preparation of the cartographic base, determination of the requirements to the materials of RSE, selection of retrospective remote information, request and obtaining of the materials of operative remote photography and their preliminary preparation, formation of educational samples and determination of deciphering features of the elements of agrarian landscapes, classification of the elements of agrarian landscapes; determination of the structure of agrarian landscape and characteristics of its elements [12].

General technological scheme of determination of arable land degradation according to the data of space photography of high space resolution is presented in Figure 1. 


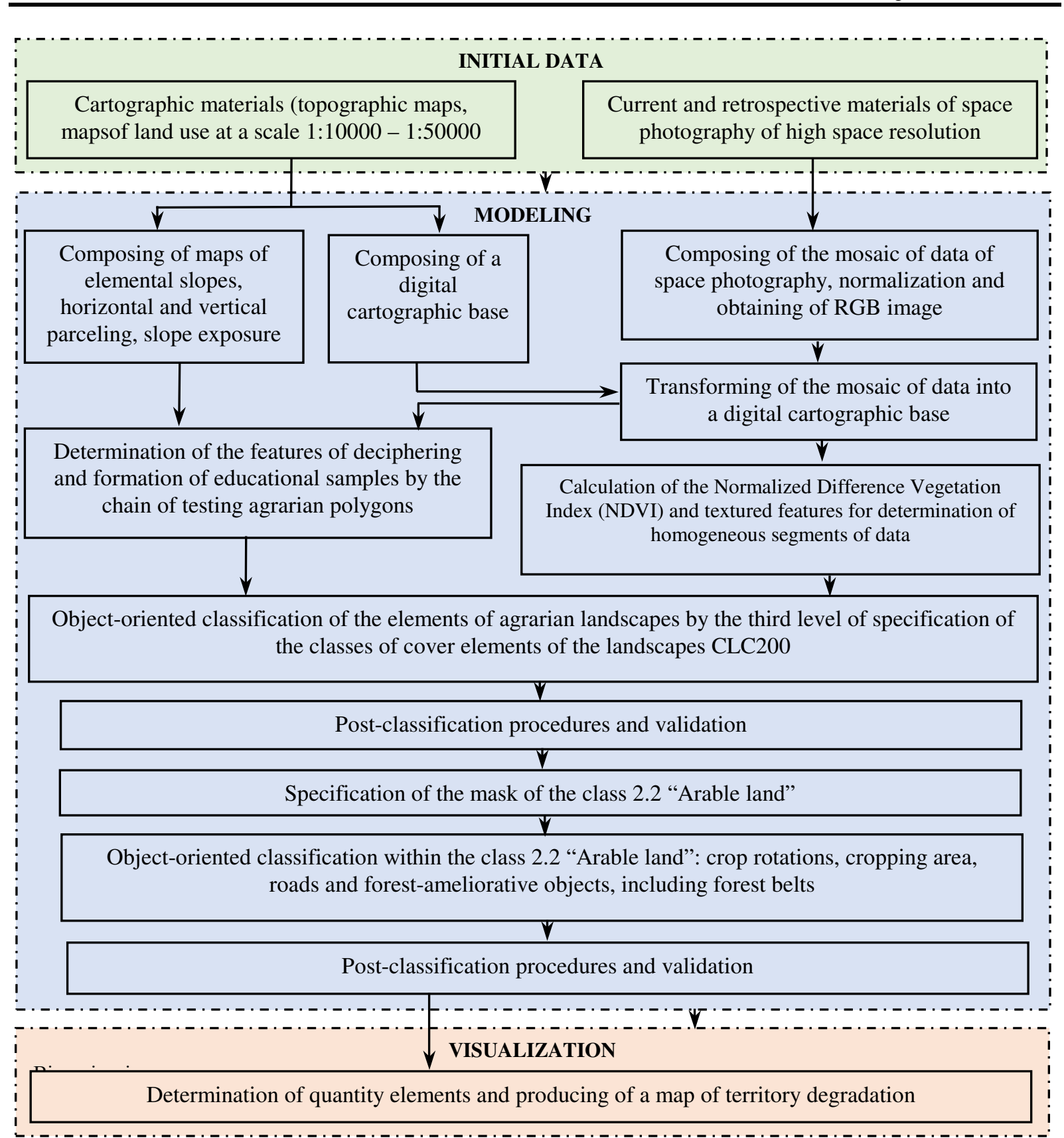

Fig. 1. General technological scheme of determination of arable land degradation according to the data of space photography of high space resolution

\section{Results and discussion}

Estimation of the degree of degradation of arable land with use of multispectral satellite images for the period 2001-2019 is presented at the local level within the village Velyka Ozymyna of Lviv region,with consideration of the local topography, type of soil and its physical properties.

To detect changes of vegetation cover and dynamics of erosion processes as two indicators, which supply the fullest characteristics of land degradation, the researchers involved additional geo-spatial data, particularly - digital model of local topography, map of soils and climatic characteristics of the studied territory. The experiment also considered the data on grading, erosions and hydrological indices of the soils, which prevailed on the examined territory.

Following processing of the satellite images required their radiometric calibration, atmospheric correction and recalculating by the coefficients of the earth surface reflection (Fig. 2). Complexity and ambiguity of the problem of remote estimation of land degradation forces the necessity of the integral analysis of heterogeneous geo-spatial data of different physical nature. It is performed on the base of a specific double-level model of raster data merging [14]. At the first level of the model, partial mapping 
of degradation was performed by each of the factors separately, which are merged at the second level into the aggregate map of land degradation. The first level of the model involved mapping of spatial distribution of the two main indicators of land degradation, i.e. changes of vegetation cover and soil erosion. The second level secured combination model of the data, obtained at the first level, into the final theme map of area degradation, using the known models and algorithms.

a)

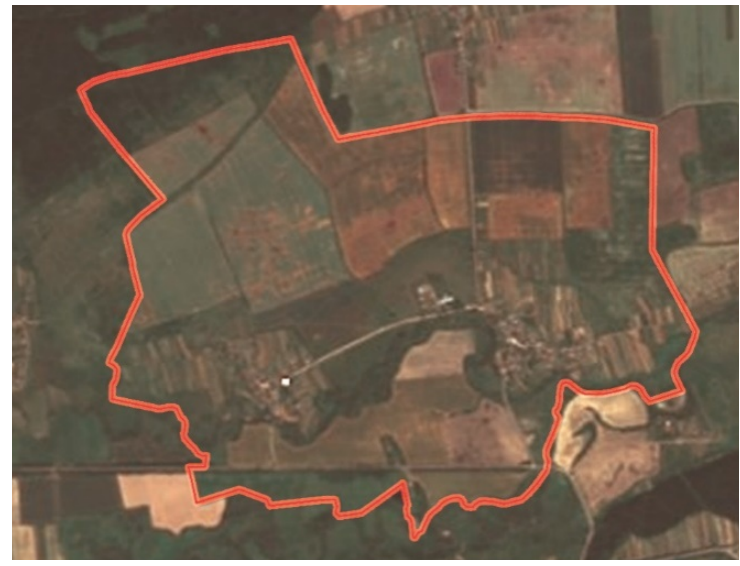

b)

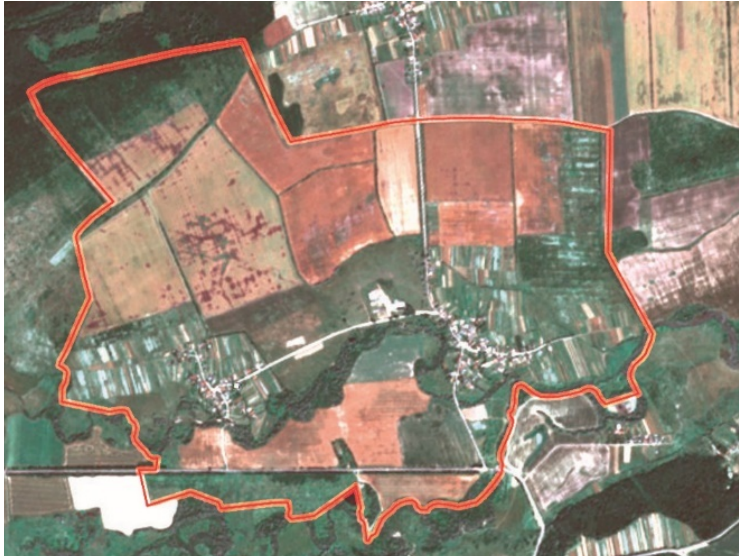

Fig. 2. Multispectral images of the satellite systemsLandsat-5, Landsat-8:

a - June, 2000; b - June, 2019; boundaries of the studied territory

Changes of vegetation cover with application of satellite images within the area of the studied territory were determined through the Normalized Difference Vegetation Index NDVI [13] (Fig. 3).

a)

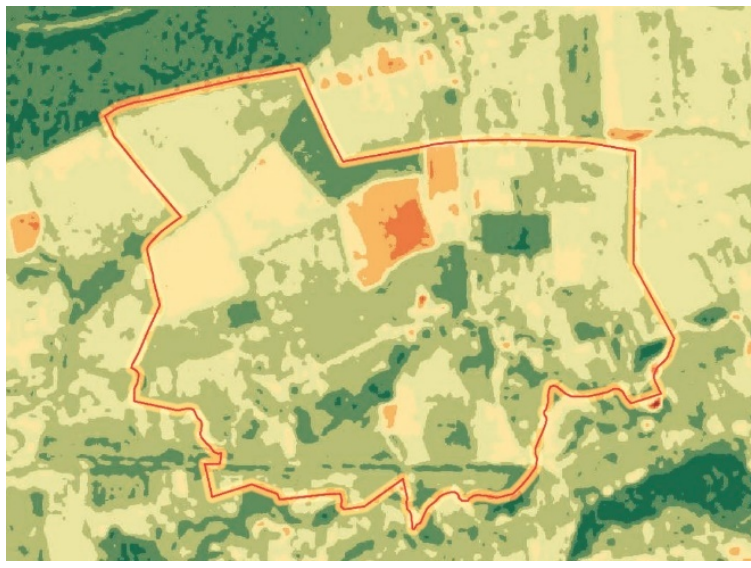

b)

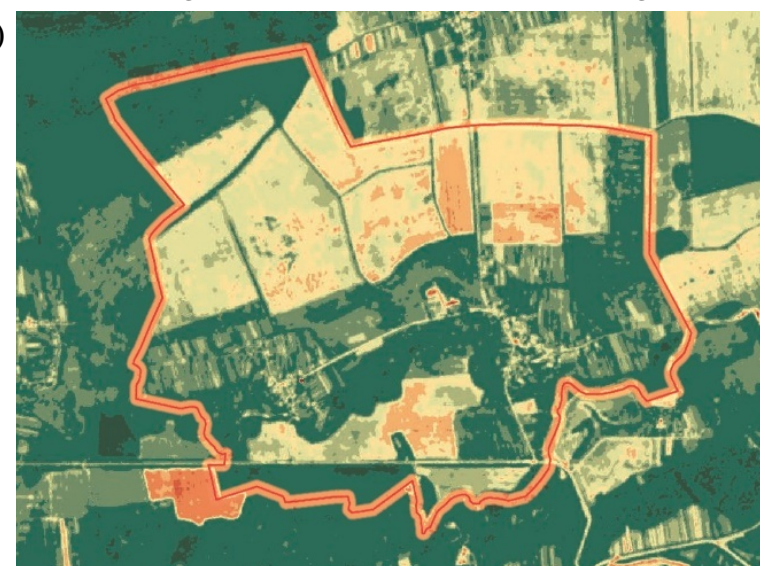

Fig. 3. Normalized Difference Vegetation Index of the studied territory:

a - June, 2000; b - June, 2019; - boundaries of the studied territory

The values of the obtained indicators are conditionally divided into seven classes of land degradation, i.e. from heavy degradation to considerable improvement [15]. Each of the indicators was assigned by its proper mask.

First three classes (considerable improvement, medium improvement, weak improvement) demonstrate positive tendencies of changes of the indices for the studied period of 2000-2019. They are illuminated by the gradient of green colour. Such indices can be considered as reduction of the risk of land quality deterioration. The fourth class (without changes) is illuminated by back colour and represents the territory, where no significant transformations have happened in 2000-2019. The last three classes (low erosion, medium erosion and high erosion) are illuminated by the gradient of red colour and represent the territory, where negative changes of the indices are observed and there is a high risk of land degradation. Degraded lands are those, which have been subjected to a considerable anthropogenic impact for nineteen years. The impact has been made by industrial and agricultural activities, causing exhaustion of land fertility.

The produced land degradation map demonstrates that, for the period of nineteen years, considerable share of the studied territory $(50.1 \%)$ has not been changed, whereas the central and southern part of the village $(18.1 \%)$ suffer from a considerable aggravating of degradation processes. 
The composed map also determines the tendencies of development of processes of land degradation within the studied territory. To make forecast of impact of climatic factors on the degree of erosion degradation of land, the authors of the research used a standard model, particularly universal equation of soil loss (Universal Soil Loss Equation) (USLE) [16]. Basing on the equation USLE, the authors developed the map of current risk of erosion degradation of soil and forecast of changes of the level of the erosion threat in case of increased extreme precipitation under permanent model parameters. The results of modelling of current and forecasted degree of erosion degradation of the territory of Velyka Ozymyna village in Lviv region are presented in Table 1.

Table 1

Forecast of the risk of soil cover erosion on arable land of Velyka Ozymyna village in Lviv region under increase of amount of extreme precipitation

\begin{tabular}{|c|c|c|c|c|}
\hline \multirow{2}{*}{$\begin{array}{c}\text { Erosion } \\
\text { threat }\end{array}$} & Class of the indicator & \multirow{2}{*}{ Symbol } & \multicolumn{2}{|c|}{$\begin{array}{c}\text { Share of degraded } \\
\text { land, \% }\end{array}$} \\
\cline { 4 - 5 } & & & $\begin{array}{c}\text { current } \\
\text { situation } \\
\text { (2000-2019) }\end{array}$ & $\begin{array}{c}\text { forecast } \\
\text { by 2050 }\end{array}$ \\
\hline Minimum & significant, medium, weak improvement & & 31.8 & 21.9 \\
\hline Weak & without changes & & 50.1 & 40.5 \\
\hline Medium & low erosion & & 12.6 & 25.9 \\
\hline High & medium erosion & & 3.6 & 7.8 \\
\hline Very high & high erosion & & 1.9 & 3.9 \\
\hline
\end{tabular}

The presented results confirm that under existing approach to use of arable land, particularly without introduction of soil-protecting measures, including field-protective forest belts, the forecasted erosion degradation of soil cover will increase twice until 2050. To cease the intensity of development of degradation processes, it is necessary to make spatial planning of the territory of rural locality on local level on the topographic-ecological base [17].

The obtained results are of great scientific value as they provide theoretical-methodological substantiation of the use of the remote sensing method for determination of the current and forecasted level of arable land degradation, because nowadays in Ukraine there are no unified methods for these purposes. Under conditions of the considerable anthropogenic burden on land resources, the proposed method will supply the latest actual and relevant information on the conditions of the soil cover layer and determine the tendencies of development of the land degradation processes that will provide appropriate and rational managerial decisions making and performance of the necessary agro-technical measures on prevention of arable land degradation.

\section{Conclusions}

1. The general technological scheme of determination of arable land degradation suggests mapping of agro-landscape elements, using materials of satellite photography of high space resolution (Landsat-5, Landsat-8), and creation of a basic map of arable land degradation at the local level. The proposed approach is approbated on the example of the village Velyka Ozymyna in Lviv region. It supplies analysis of the erosion processes spreading over the arable land in the period 2000-2019, and modelling of the forecasted level of land degradation by 2050.

2. It is determined that within existing system of economic activity on the studied territory, by 2050 the share of degraded land will achieve $38 \%$, according to the indicator of erosion process development. The figure is for $19 \%$ higher than the area of eroded land in 2019. To cease the dynamics of development of the land degradation processes, it is important to make spatial planning of rural territory on the topographic-ecological base and to perform soil-protective measures.

3. The proposed approach to determination and forecasting of the processes of arable land degradation at the local level with application of space images of high space resolution is significant for Ukraine, Latvia and Azerbaijan. It is based on the indicators of land degradation, which are common for all countries - changes of vegetation cover and dynamics of the processes of soil erosion. That experience is also operative, available and comfortable in use. 


\section{References}

[1] Зацерковний В. I. Застосування геоінформаційних систем у задачах ефективного землекористування(Application of geo-informational systems in the problems of efficient land use. Scientific works). Наукові праці. Техногенна безпека. Радіобіологія, т. 261, вип. 249, 2015, pp. 14-21. (In Ukrainian).

[2] Agriculture. [online] [02.03.2020]. Available at: http://www.fao.org/ag/agn/nutrition/Indicatorsfiles/Agriculture.pdf

[3] Glossary: Eurostat. [online] [02.03.2020]. Available at: https://ec.europa.eu/eurostat/statisticsexplained/index.php?title = Glossary:Arable_land

[4] FAO Statistics. [online] [14.03.2020]. Available at: http://www.fao.org/statistics/en/

[5] Campbell P. The Future Prospects for Global Arable Land. Australia, 2011. 6 p. [online] [04.03.2020]. Available at: http://www.futuredirections.org.au/publication/the-future-prospectsfor-global-arable-land/

[6] Kanianska R. Agriculture and Its Impact on LandUse, Environment, and Ecosystem Services. 2016. [online] [09.03.2020]. Available at: https://www.intechopen.com/books/landscape-ecologythe-influences-of-land-use-and-anthropogenic-impacts-of-landscape-creation

[7] Panagos P., Borrelli P., Poesen J., Ballabio C., Lugato E., Meusburger K., Montanarella L., Alewell C. The new assessment of soil loss by water erosion in Europe. Environmental Science \& Policy, 2015, Vol. 54, pp. 438-447.

[8] Nkonya E., Mirzabaev A., Braun J. Economics of Land Degradation and Improvement - A Global Assessment for Sustainable Development. Springer Cham Heidelberg New York Dordrecht London, 2016. $686 \mathrm{p}$.

[9] Parsova V., Stoiko N., Kuryltsiv R., Kryshenyk N. Differentiation of land cover degradation in Ukraine and Latvia. Engineering for Rural Development. Proceedings of the 18th International Scientific Conference. Vol.18, May 22-24, 2019, Jelgava, Latvia, pp. 798-803. DOI: 10.22616/ERDev2019.18.N209.

[10] Carlson T.N., Ripley D.A. On the relation between NDVI, fractional vegetation cover, and leaf area index. Remote Sensing of Environment, Vol.62, 1997, No.3, pp. 241-252.

[11] Jones L., Goldberg E. Mapping and monitoring land degradation risks in the Western Brazilian Amazon using multitemporal landsat tm/etm. Land degradation \& development, Land 18, 2007, pp. 41-54.

[12]Методичні рекомендації з агроекологічної оцінки структури агроландшафтів і систем землекористування за даними дистанційного зондування Землі високого просторового розрізнення (Methodic recommendations on agro-ecological evaluation of the structure of agrarian landscapes and systems of land use according to the data of remote sensing of the Earth of high space resolution). Київ, 2012. 34 c. (In Ukrainian).

[13] Data application of the month: Land degradation. [online] [03.03.2020]. Available at: http://www.un-spider.org/links-and-resources/data-sources/daotm-land-degradation.

[14] Stankevich S.A., Vasko A.V., Gubkina V.V. Two-level model for land degradation mapping on multispectral satellite imagery. Proceedings of the 8th International Conference on Digital Technologies (DT'2011). University of Žilina, 2011, pp. 289-293.

[15] Дудар Т.В., Станкевич С.А., Лоїк В.І., Мартинова О.В. Дослідження деградації земельних ресурсів калуського району Івано-Франківської області з використанням геоінформаційних технологій (Investigation of the degradation of land resources of Kalush district in IvanoFrankivsk region with application of geo-informational technologies). Наукоємні технологіï, № 4 (16), 2012, pp. 116-120. (In Ukrainian).

[16] Stoiko N., Kryshenyk N. Methodical approach as to improvement of organization of land utilization and protection in erosion-unsafe agrolandscapes. International scientific journal "Baltic Surveying", Vol. 3, 2015, pp. 54-61.

[17] Parsova V., Stoiko N., Kryshenyk N. Landscape-ecological requirements for spatial planning of rural territories of Ukraine. Engineering for Rural Development. Proceedings of the 17th International Scientific Conference. Vol.17, May 23-25, 2018, Jelgava, Latvia, pp. 445-450. DOI: 10.22616/ERDev2018.17.N027 